\title{
ELECTROPHYSIOLOGICAL AND PHARMACOLOGICAL CHARACTERISTICS OF THE SEROTONIN RESPONSE ON A VERTEBRATE NEURONAL SOMATIC CELL HYBRID ${ }^{1}$
}

\author{
JOSEPH E. FRESCHI ${ }^{2}$ AND WILLIAM G. SHAIN ${ }^{3}$
}

Physiology Department, Armed Forces Radiobiology Research Institute, Bethesda, Maryland 20814

Received April 21, 1981; Revised September 21, 1981; Accepted September 24, 1981

\begin{abstract}
We studied the effects of 5-hydroxytryptamine (5-HT, serotonin) on the vertebrate neuronal somatic cell hybrid TCX11. We compared electrophysiological and pharmacological properties of the 5-HT response to those of the dopamine (DA) response. The cells developed delayed rectification and the ability to generate action potentials. Both 5-HT and DA caused graded depolarizations associated with increases in membrane conductance. The cells, however, were 10 to 100 times more sensitive to 5-HT than to DA. Responses to the amines desensitized during sequential or continuous application, and each neurotransmitter could desensitize the cell to a subsequent dose of the other neurotransmitter (cross-desensitization). Reversal potentials for both amines ranged from 0 to 15 $\mathrm{mV}$ from cell to cell, but on any given cell, the reversal potentials for 5-HT and DA were equal. We applied a variety of drugs, including classical DA and 5-HT antagonists, and found no drug that blocked the response to one amine without a similar inhibition of the response to the other amine.

We conclude that, on the hybrid TCX11, there is a receptor that mediates a depolarizing response with a conductance increase after interaction with $5-\mathrm{HT}$ and DA. Our data suggest that the receptor is best classified as a serotonin receptor.
\end{abstract}

Physiological study of serotonin (5-HT) receptors in both the central and peripheral nervous systems has been complicated by several factors. First, the intact nervous system is complex, and studying discrete cellular mechanisms in an unequivocal manner is difficult. Second, there are subtypes of 5 -HT receptors, so that data derived from a research technique that adequately explores the properties of one receptor subtype may conflict with data from a technique suitable for studying another receptor subtype. For example, in some systems, 5-HT-coupled adenylate cyclase differs from the 5-HT receptor mediating an electrophysiological response (MacDermot et al., 1979) or from the receptors labeled by certain high affinity ligands (Peroutka and Snyder, 1979; Leysen et al., 1978). Third, there may be agonist and antagonist crossreactivity among several receptors, such as 5-H'T, dopa-

\footnotetext{
${ }^{1}$ This work was supported by the Armed Forces Radiobiology Research Institute, Defense Nuclear Agency, under Research Work Unit MJ 00039. The views presented in this paper are those of the authors. No endorsement by the Defense Nuclear Agency has been given or should be inferred.

${ }^{2}$ To whom correspondence should be addressed.

${ }^{3}$ Present address: Division of Laboratories and Research, New York State Department of Health, Empire State Plaza, Albany, NY 12201.
}

mine (DA), or noradrenaline (NA) receptors (Enjalbert et al., 1978; Twarog et al., 1977).

Cell lines offer the advantage of large numbers of homogeneous cells that may be studied under easily controlled conditions. Myers et al. (1977) reported that the neuronal somatic cell hybrid TCX11 (neuroblastoma $X$ mouse sympathetic ganglion) depolarizes after application of dopamine or serotonin. This cell line, if it possesses separate DA and 5-HT receptors, could be useful for comparative pharmacological studies of possible agonists and antagonists.

Since Myers et al. (1977) had attempted to characterize the properties of the DA response, we sought to examine the 5-HT response and compare its electrophysiological and pharmacological properties to those of the dopamine response.

\section{Materials and Methods}

Cell culture techniques. TXC11 is a subclone of a somatic cell hybrid derived from the fusion of mouse neuroblastoma cells (N18TG2) with mouse sympathetic ganglion cells (Greene et al., 1975). The cells were grown in a modified F12 medium (Vogel et al., 1972) deficient in tyrosine and supplemented with carbachol, additional hypoxanthine, aminopterine, and additional thymidine 
(Myers et al., 1977). The medium was supplemented further with $5 \%(\mathrm{v} / \mathrm{v})$ fetal bovine serum. Culture dishes were maintained at $37^{\circ} \mathrm{C}$ in a humidified $5 \% \mathrm{CO}_{2}, 95 \%$ air atmosphere. The medium was changed three times per week. For electrophysiological studies, the cells were grown in 35-mm culture dishes, and the medium was supplemented with $1 \mathrm{mM} N^{6}, O^{2 \prime}$-dibutyryl cyclic $3^{\prime}: 5^{\prime}$ monophosphoric acid (dbcAMP). The addition of dbcAMP was required to induce morphological and electrophysiological differentiation (Furmanski et al., 1971). In addition, the medium was supplemented (30\% to $40 \%$, $\mathrm{v} / \mathrm{v}$ ) with growth medium removed from dishes of TCX11 cells in log phase growth. The addition of this conditioned medium was necessary for the expression of chemosensitivity (Myers et al., 1977).

Electrophysiology. Dishes were transferred to a chamber mounted on the stage of an inverted phase microscope. The medium was maintained at $37^{\circ} \mathrm{C}$ by a substage resistive heating element. Acid-base balance was maintained by passing warm, humidified $10 \% \mathrm{CO}_{2}, 90 \%$ air over the surface of the medium to which had been added a thin layer of mineral oil to retard evaporation and retain heat. Microelectrodes pulled from glass pipettes containing a fused inner fiber were filled with either $3 \mathrm{M} \mathrm{KCl}$ or $4 \mathrm{~m}$ potassium acetate and had resistances of 50 to 150 megohms. The indifferent and currentmeasuring electrodes were $3 \mathrm{M} \mathrm{KCl}$-agar bridges. All electrodes and bridges were connected to the system electronics via a $3 \mathrm{M} \mathrm{KCl}-\mathrm{Ag}-\mathrm{AgCl}$ junction. Membrane potential was measured with a high input impedance unity gain differential amplifier equipped with negative capacitance feedback and an active bridge circuit. The latter was used to record membrane potential simultaneously while passing current. Current was measured using an operational amplifier that converts current to voltage and clamps the bath at virtual ground. Voltage and current were monitored and photographed on a storage oscilloscope and measured with a four-channel pen recorder. For iontophoresis, glass microelectrodes fabricated as above were filled with dopamine hydrochloride (1 $\mathrm{M}, \mathrm{pH} 3$ to 5 ) and 5-hydroxytryptamine hydrochloride (1 $\mathrm{M}, \mathrm{pH} 3$ to 5 ) or 5-hydroxytryptamine creatinine sulfate ( $40 \mathrm{~mm}, \mathrm{pH} 3$ to 5). Positive current pulses from a constant current generator (W-P Instruments 160) were used to iontophorese the drugs. A small negative braking current was needed to prevent diffusion of the drug from the pipette tip. Both DA and 5-HT iontophoretic pipettes were held in a small assembly with which the electrode tips could be approximated to within $5 \mu \mathrm{m}$ of each other. This assembly then was mounted on a micromanipulator and moved into position to maintain a rather constant spatial relationship between the two drug pipettes.

Pharmacology. Drugs were dissolved in the same medium that bathed the cells. The drugs then were applied directly to the bath. Approximately $10 \mathrm{~min}$ were required for complete mixing. Alternatively, for some experiments, drugs dissolved in medium were perfused rapidly onto cells via a perfusion pipette having a tip diameter of about 15 to $20 \mu \mathrm{m}$.

\section{Results}

Passive and active electrical membrane properties. The average resting membrane potential of these cells was $-50 \mathrm{mV}(\mathrm{SD} \pm 9)$ and the average input resistance was 38.5 megohms (SD \pm 11$)$. These results agree with data previously reported (Myers et al., 1977). Most cells studied had nonlinear current-voltage (I-V) relationships. Outward rectification was prominent when we depolarized the membrane beyond about $-40 \mathrm{mV}$ (Fig. $1, A$ and $B)$. Many cells exhibited action potentials following hyperpolarizing (anodal break) current pulses. When we shifted the membrane potential to levels more negative than $-60 \mathrm{mV}$, by passing steady hyperpolarizing current,
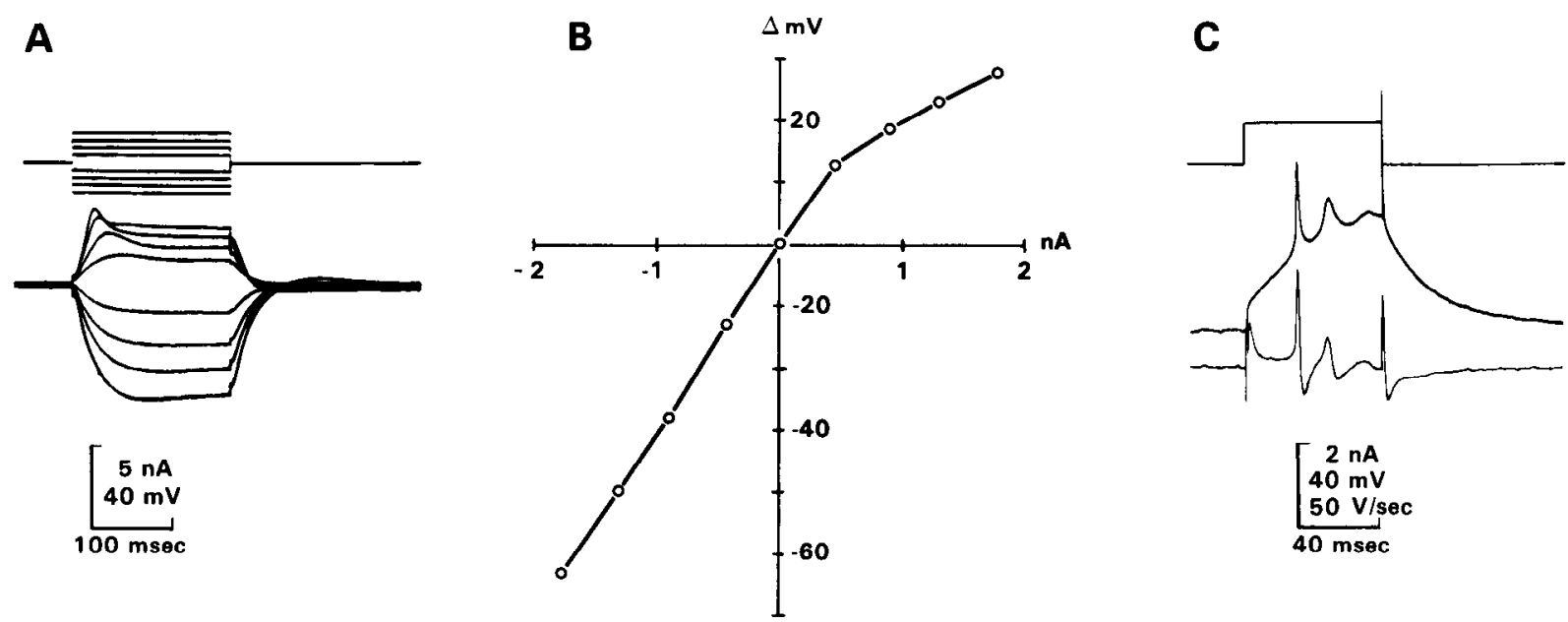

Figure 1. TCX11 electrical membrane properties. A, Voltage responses to constant current pulses of various amplitudes. Records were made using two microelectrodes: one for passing current (upper traces) and one for recording voltage (bottom traces). The resting membrane potential was $-60 \mathrm{mV}$ (adjusted from $-50 \mathrm{mV}$ by passing steady inward current). $B$, Currentvoltage characteristics of same cell as $A$. The origin of the graph represents the adjusted resting membrane potential. $C$, Action potential evoked by a depolarizing current pulse in another cell. The resting potential shifted to $-80 \mathrm{mV}$. Top trace, current; middle trace, voltage; bottom trace, derivative of voltage with respect to time $(d V / d t)$. Current passed through the voltagemeasuring electrode via the bridge circuit in $C$ and all subsequent figures. 


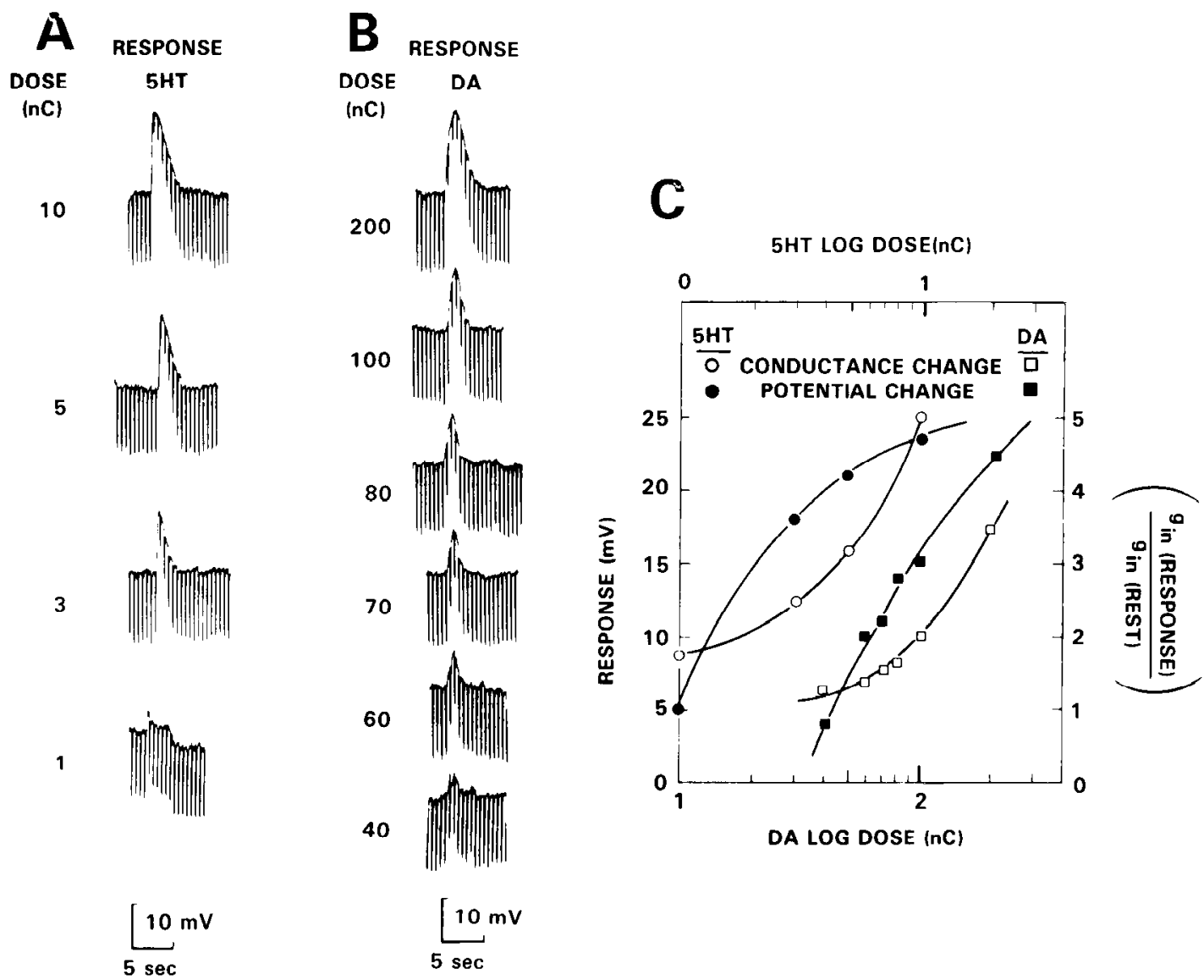

Figure 2. Dose-response relationships for 5-HT and DA on a TCX11 cell. $A$, Voltage and input resistance changes evoked by $5-\mathrm{HT}$. The amount of charge iontophoresed from the 5-HT pipette is indicated to the left of each trace. Resistance was monitored by repetitively passing hyperpolarizing constant current pulses across the membrane. $B$, Voltage and input resistance changes evoked by DA. The traces were generated as in $A . C$, Graphic representation of $A$ and $B$. Note the different scales for DA and 5-HT abscissas. Lines were drawn by eye.

we could evoke action potentials with depolarizing current pulses (Fig. $1 C$ ).

Responses to iontophoretically applied dopamine and serotonin. Iontophoresis of $5-\mathrm{HT}$ caused a rapid depolarization of the membrane potential and an increase in input conductance (Fig. $2 A$ ). Dopamine also evoked a depolarization and an increased membrane conductance (Fig. 2B).

We made a comparison of the potencies of the two amines in more than 30 cells. We found no response in about $30 \%$ of the cells. Of the remaining $70 \%$ of the cells, all responded to both amines (none responded to one drug and not to the other). For all of the cells that responded, 10 to 100 times more DA (as expressed by iontophoretic current) was required in order to obtain a response of magnitude similar to that obtained with 5HT (Fig. 2C).

We do not know the transport numbers of DA and 5$\mathrm{HT}$ pipettes. We measured the relative conductivities of $1 \mathrm{~m}$ solutions of the hydrochloride salts of DA and 5-HT and found them to be equal. Because the two drugs have similar molecular weights and structures and the same relative conductivity, we assume that the transport numbers are similar. If, however, the transport properties of the two drug pipettes are dissimilar, we consider it un- likely that the inequality is of such magnitude that it accounts for the 10 - to 100 -fold difference in drug potencies.

Desensitization. Sequential doses of 5-HT resulted in a decrease in amplitude of subsequent conductance and potential changes (Fig. 3A2). After large doses, the period of relative desensitization could last from 1 to $2 \mathrm{~min}$. Sequential doses of DA also caused a refractory period (Fig. 3A1), but after large doses, the period of desensitization was never as long as that caused by 5 -HT.

Tests for cross-desensitization between 5-HT and DA produced consistent results only when we reduced the 5HT dose to levels representing approximately the same place on the dose-response curve as that for the dopamine dose. This is illustrated in Figure 3, $B$ and $C$, where we compare the results from testing cross-desensitization using equal DA and 5-HT doses (Fig. $3 B$ ) with the results from doses giving equivalent responses (Fig. $3 C$ ). When one compares equal responses, it is clear that application of one neurotransmitter ${ }^{4}$ renders the cell less responsive

\footnotetext{
${ }^{4}$ We use the term neurotransmitter in reference to DA and 5-HT. We do not imply that these amines are neurotransmitters specifically in this culture system; there are no synaptic contacts among TCX11 cells.
} 
A 1

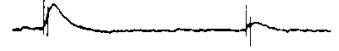

DA $200 \mathrm{nC}$ DA
$200 \mathrm{nC}$
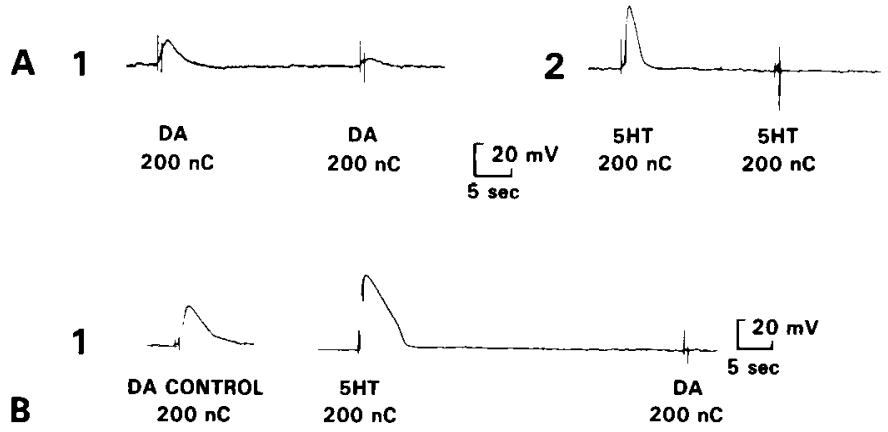

2

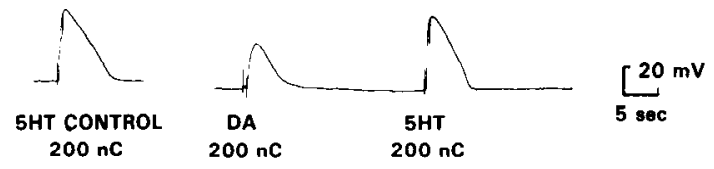

CONTROL

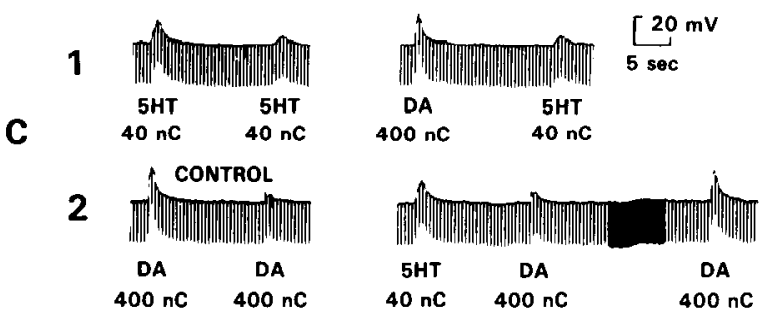

Figure 3. Cross-desensitization of 5-HT and DA responses. Sequential doses of DA $(A 1)$ and 5-HT $(A 2)$ cause reduction in the response amplitude. When large equal doses of 5-HT and DA are used, 5-HT desensitizes the cell to the subsequent DA dose $(B 1)$, but DA does not appear to affect the response of the cell to the subsequent 5-HT dose (B2). When the 5-HT dose is lowered to the amount that causes the response equal to that caused by DA, each amine reduces the responsiveness of the cell to the subsequent dose of the other amine (C). $A, B$, and $C$ are from different cells.

to the other neurotransmitter. Thus, the two amines cross-desensitize.

Reversal potentials. We could shift and hold the membrane potential at various levels by passing steady current through the recording electrode while the bridge remained in balance. As we progressively depolarized the membrane, the amplitude of the 5-HT response decreased until a null was reached at membrane potentials of 0 to $15 \mathrm{mV}$. Thereafter, the response inverted and increased in amplitude as we further shifted the membrane to more positive levels (Fig. 4). Although the null or reversal potential varied from cell to cell, when we examined both DA and 5-HT responses on the same cell $(n=5)$, the reversal potentials were equal (Fig. 4). The reversal potentials for DA and 5-HT on the same cell were shifted equally to more negative values in low sodium medium in the single experiment in which this was tested.

Pharmacology. We applied a wide variety of drugs for two reasons. First, we wished to determine which drugs might be 5-HT antagonists. Second, we wanted to determine whether a drug could block the response of one of the neurotransmitters without affecting the action of the other. For these reasons, we did not attempt quantitative dose-response relationships but rather used a single high concentration of a drug for rapid screening purposes.

In Table I are listed all of the drugs tested to date. All drugs blocked both the 5-HT and the DA response when added to the bath in the indicated concentrations (see example, Fig. 5). Thus, we found no drug that selectively inhibits the response to one amine and does not block the response to the other. We further tested four of the drugs in Table I by applying them with a blunt pipette, thereby ensuring rapid perfusion. In this way, we found that some of the drugs that blocked the $5-\mathrm{HT}$ and DA responses when bath applied, depolarized and increased the input conductance of the membrane when rapidly applied (Fig. 6, $A$ to $C$ ). Cinnanserin was the only one of the four drugs tested in this way that did not affect the membrane directly but blocked the neurotransmitter response (Fig. 6D).

\section{Discussion}

These results indicate that, on the neuronal somatic cell hybrid TCX11, there is a receptor that mediates a depolarization and increase in input conductance of the membrane after interaction with biogenic amines. For the following reasons, the evidence that we present here suggests that the indolamine serotonin and the catecholamine dopamine act at the same receptor and that the receptor is best classified as a $5-\mathrm{HT}$ receptor. First, the cell is 10 to 100 times more sensitive to 5 -HT than to DA. Second, no cell responded to one amine and not to the other. Third, the two amines cross-desensitize. Fourth, the two neurotransmitters have the same reversal potential. Fifth, all drugs found to block the response to one amine also inhibited the response to the other. Other amines were examined by Myers et al. (1977) and found to be ineffective agonists. We confirmed that noradrenaline is a much weaker agonist than even dopamine (J. E. Freschi and W. G. Shain, unpublished observation).

Our results and conclusions substantially differ from those presented by the only other group that studied this cell line. We found rectifying and active electrical membrane properties in contrast to the ohmic electrical properties described by Myers et al. (1977). Because morphological and, pari passu, electrophysiological differentiation increases with time in dbcAMP, the differences in electrical membrane properties may have occurred because our cultures were older and further morphologically differentiated and because we selected the more neuronal appearing cells for study. Myers et al. (1977) determined the reversal potential for the two amines separately in different cells. We determined reversal potentials for DA and 5-HT on the same cell and found that, although the range of reversal potentials may be rather large from cell to cell, they were always the same on the same cell. Myers et al. (1977) used equal doses of 5-HT and DA in testing for cross-desensitization and in studying pharmacology. Before performing such comparative investigations, we adjusted the dose until the two amines produced similar responses. Only in this way can one appreciate the similar effects on the dose-response curves of the two amines.

Our pharmacological studies showed that there was no inhibition of one neurotransmitter response without a 
A CELL 1

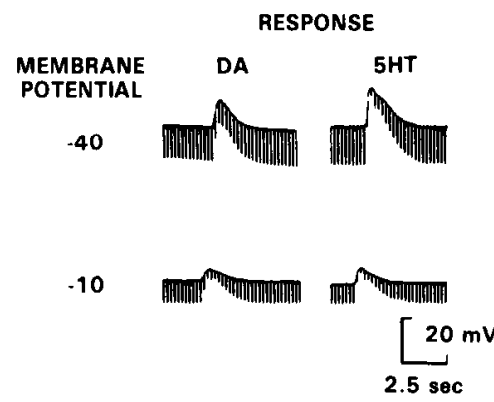

o

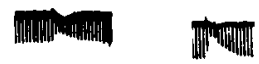

10

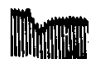

B CELL 2

RESPONSE

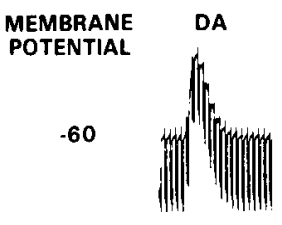

$-25$

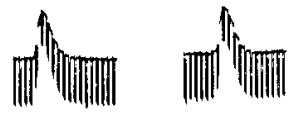

0

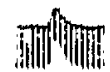

20
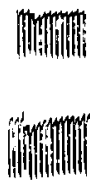
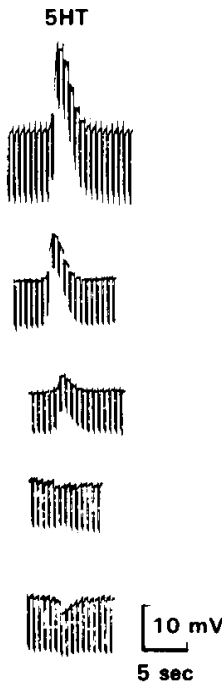

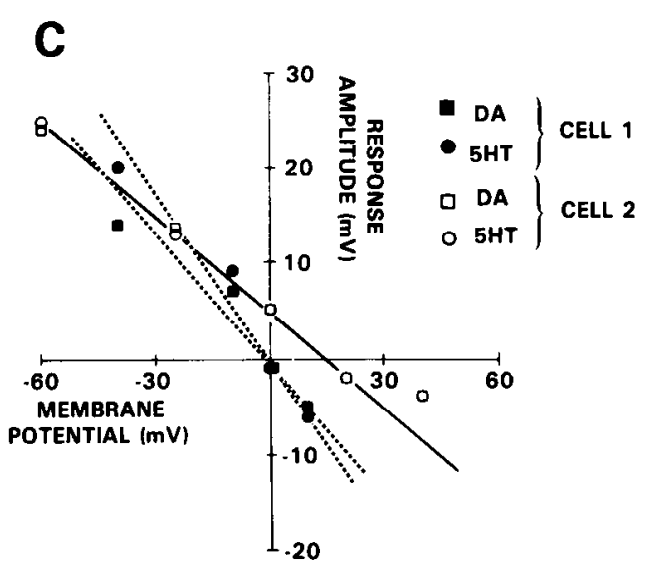

Figure 4. Reversal potentials of 5-HT and DA responses. $A$, Voltage responses to equal size doses of DA and 5-HT at various membrane potentials indicated to the left of each trace pair. $B$, Same as $A$ except that the 5-HT dose was reduced to give a voltage and conductance change similar to that caused by the DA dose. $C$, Graph of the data shown in $A$ and $B$. Lines were drawn by eye.

TABLE I

Drugs that have a blocking effect on 5-HT and DA responses when applied to bath

\begin{tabular}{|c|c|c|}
\hline DRUG & $\begin{array}{l}\text { CONCENTRATION } \\
\text { USED IN } \\
\text { EXPERIMENT }(\mu \mathrm{M})\end{array}$ & CLASSIFICATION \\
\hline$(+)$-TUBOCURARINE & 1 & $\begin{array}{l}\text { RECEPTOR - COUPLED Na+ AND CI- } \\
\text { CHANNEL BLOCKER }\end{array}$ \\
\hline PHENTOLAMINE* & 100 & a-ADRENORECEPTOR BLOCKER \\
\hline $\begin{array}{l}\text { BULBOCAPNINE } \\
\text { CHLORPROMAZINE }\end{array}$ & $\begin{array}{l}100 \\
100\end{array}$ & $\begin{array}{l}\text { DOPAMINE ANTAGONIST } \\
\text { DOPAMINE ANTAGONIST }\end{array}$ \\
\hline $\begin{array}{l}\text { METHIOTHEPIN } \\
\text { CYPROHEPTADINE* }\end{array}$ & $\begin{array}{l}100 \\
100\end{array}$ & $\begin{array}{l}\text { SEROTONIN ANTAGONIST } \\
\text { SEROTONIN ANTAGONIST }\end{array}$ \\
\hline $\begin{array}{l}\text { CINNANSERIN* } \\
\text { BROMO-LSD** }\end{array}$ & $\begin{array}{r}10 \\
100\end{array}$ & $\begin{array}{l}\text { SEROTONIN ANTAGONIST } \\
\text { SEROTONIN ANTAGONIST }\end{array}$ \\
\hline $\begin{array}{l}\text { METHYLSERGIDE } \\
\text { METERGOLINE }\end{array}$ & $\begin{array}{l}50 \\
50\end{array}$ & $\begin{array}{l}\text { SEROTONIN ANTAGONIST } \\
\text { SEROTONIN ANTAGONIST }\end{array}$ \\
\hline MERSALIC ACID & 100 & SEROTONIN ANTAGONIST \\
\hline
\end{tabular}

- DRUGS ALSO TESTED BY APPLICATION WITH PERFUSION PIPETTE. 


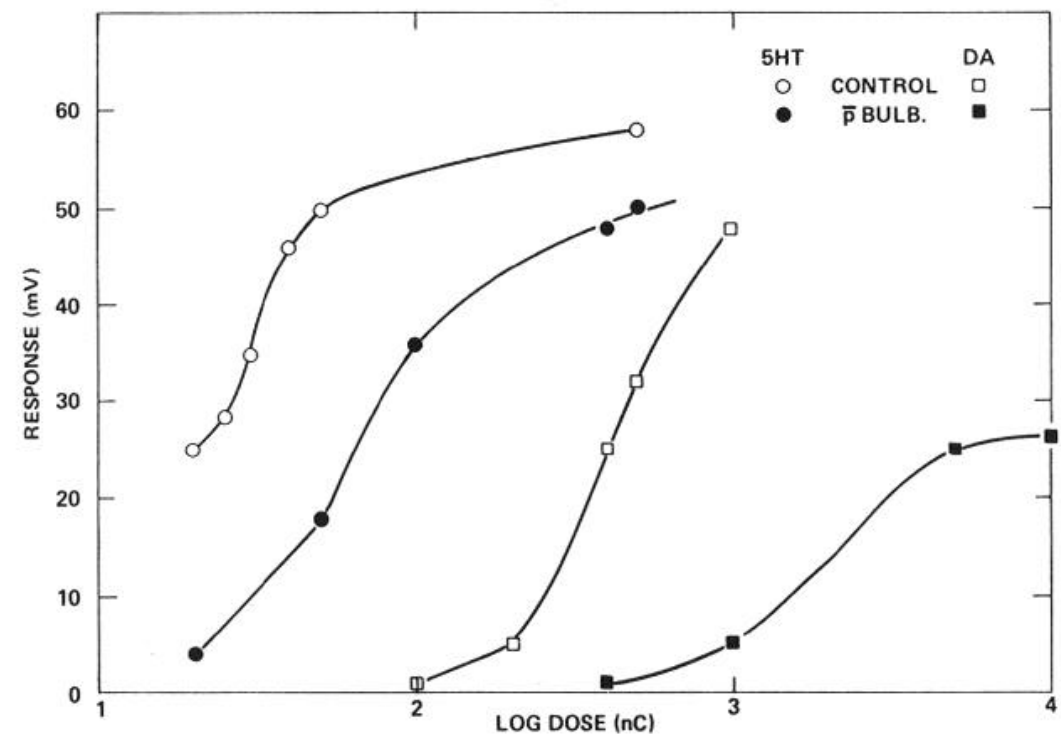

Figure 5. Example of the effect of bulbocapnine (BULB.) on 5-HT and DA dose-response curves. The drug shifts both curves to right by about 0.5 $\log$ unit. The depression of the peak of the post-drug DA curve probably represents desensitization and also may reflect the technical limitations of iontophoresing such large currents.
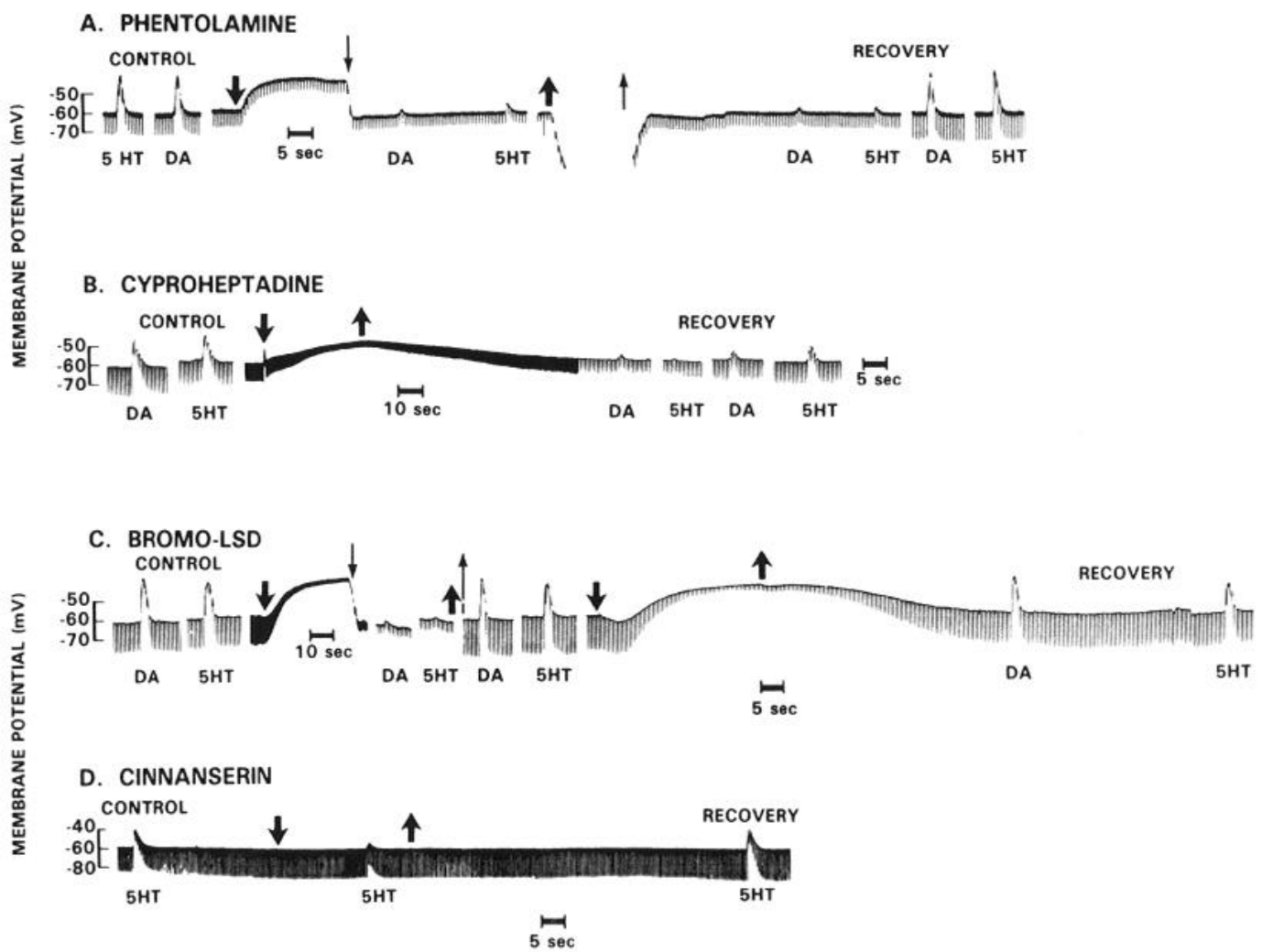

Figure 6. Effects of drugs applied by a perfusion pipette. Experiments $A$ to $D$ were done with different cells. In each experiment, the large arrows indicate the application and withdrawal of the test drug; small arrows show the passage of steady inward current to hold the cell at about -60 $\mathrm{mV}$. Of the four drugs tested in this way, only cinnanserin blocked the 5-HT (and DA) response without having a direct effect on membrane conductance $(D)$.

similar inhibition of the other. It is clear from the rapid perfusion studies that, in the concentrations used, some of the drugs that appeared to be 5-HT antagonists when bath applied could have been agonists that simply desensitized the membrane to the neurotransmitters. Further- more, because rather high doses were used, the results do not address the possibility that some of these drugs may have had partial agonist-antagonist effects in a concentration-dependent manner. Further studies are required in which dose-response curves for $5-\mathrm{HT}$ and DA 
are established in the presence of varying concentrations of test drugs and the effects of the test drugs are studied by rapid perfusion to minimize desensitization.

The 5-HT response on TCX11 appears similar to that on a number of autonomic neurons (Wallis and North, 1978; Higashi, 1977), on several neuroblastoma-derived cell lines (Christian et al., 1978; MacDermot et al., 1979), and in some invertebrate systems (Gerschenfeld and Paupardin-Tritsch, 1974; Twarog et al., 1977). Since a rather limited pharmacological survey has been done on these other systems and on our cell line, it is impossible to compare them in any detail. In addition, excitatory 5HT responses occur in the central nervous system (Boakes et al., 1970; Briggs, 1977; McCall and Aghajanian, 1979), but they have not been characterized at the cellular level and therefore cannot be compared to TCX11. It remains unclear, then, whether this cell line can serve as a model for central 5-HT receptors. On the other hand, it may be a useful model for peripheral 5-HT receptors. Receptors present on autonomic neuron somata upon which no 5-HT synapses impinge may be regarded as possible remnants of those receptors that migrated down the axon during development. If these somal receptors are representative of the presynaptic terminal receptors (see Deshenes et al., 1976), then cell lines such as TCX11 may be useful for microelectrode experiments that would be impossible to perform on the axon terminals themselves.

\section{References}

Boakes, R. J., P. B. Bradley, I. Briggs, and A. Dray (1970) Antagonism of 5-hydroxytryptamine by LSD-25 in the central nervous system: A possible neuronal basis for the actions of LSD-25. Br. J. Pharmacol. 40: 202-218.

Briggs, I. (1977) Excitatory responses of neurons in rat bulbar reticular formation to bulbar raphe stimulation and to iontophoretically applied 5-hydroxytryptamine, and their blockade by LSD 25. J. Physiol. (Lond.) 265: 327-340.

Christian, C. N., P. G. Nelson, P. Bullock, D. Mullinax, and M. Nirenberg (1978) Pharmacologic responses of cells of a neuroblastoma $\times$ glioma hybrid clone and modulation of synapses between hybrid cells and mouse myotubes. Brain Res. 147: 261-276.

Deshenes, M., P. Feltz, and Y. Lamour (1976) A model for an estimate in vivo of the ionic basis of presynaptic inhibition:
An intracellular analysis of the GABA-induced depolarization in rat dorsal root ganglia. Brain Res 118: 486-493.

Enjalbert, A., M. Hamon, S. Bourgoin, and J. Bockaert (1978) Postsynaptic serotonin-sensitive adenylate cyclase in the central nervous system. II. Comparison with dopamine- and isoproterenol-sensitive adenylate cyclases in rat brain. Mol. Pharmacol. 14: 11-23.

Furmanski, P., D. J. Silverman, and M. Iubin (1971) Fxpression of differentiated functions in mouse neuroblastoma mediated by dibutyryl-cyclic adenosine monophosphate. Nature 233: 413-415.

Gerschenfeld, H. M., and D. Paupardin-Tritsch (1974) Ionic mechanisms and receptor properties underlying the responses of molluscan neurones to 5-hydroxytryptamine. J. Physiol. (Lond.) 243: 427-456.

Greene, L. A., W. G. Shain, A. Chalazonitis, X. Breadfield, J. Minna, H. G. Coon, and M. Nirenberg (1975) Neuronal properties of hybrid neuroblastoma $\times$ sympathetic ganglion cells. Proc. Natl. Acad. Sci. U. S. A. 72: 4923-4927.

Higashi, H. (1977) 5-Hydroxytryptamine receptors on visceral primary afferent neurones in the nodose ganglion of the rabbit. Nature 267: 448-450.

Leysen, J. E., C. J. E. Niemegeers, J. P. Tollenaere, and P. M. Laduron (1978) Serotonergic component of neuroleptic receptors. Nature 272: 168-171.

MacDermot, J., H. Higashida, S. P. Wilson, H. Matsuzawa, J. Minna, and M. Nirenberg (1979) Adenylate cyclase and acetylcholine release regulated by separate serotonin receptors of somatic cell hybrids. Proc. Natl. Acad. Sci. U. S. A. 76: 1135-1139.

McCall, R. B., and G. K. Aghajanian (1979) Serotonergic facilitation of facial motoneuron excitation. Brain Res. 169: 1127.

Myers, R., D. R. Livengood, and W. G. Shain (1977) Characterization of a depolarizing dopamine response in a vertebrate neuronal somatic cell hybrid. J. Cell. Physiol. 91: 103-118.

Peroutka, S. J., and S. H. Snyder (1979) Multiple serotonin receptors: Differential binding of $\left[{ }^{3} \mathrm{H}\right]$ lysergic acid diethylamide and $\left[{ }^{3} \mathrm{H}\right]$ spiroperidol. Mol. Pharmacol. 16: 687-699.

Twarog, B. M., Y. Muneoka, and M. Ledgere (1977) Serotonin and dopamine as neurotransmitters in Mytilus: Block of serotonin receptors by an organic mercurial. J. Pharmacol. Exp. Ther. 201: 350-356.

Vugel, A., A. J. Sytkowski, and M. Nirenberg (1972) Acetylcholine receptors of muscle grown in vitro. Proc. Natl. Acad. Sci. U. S. A. 69: 3180-3184.

Wallis, D. I., and R. A. North (1978) The action of 5-hydroxytryptamine on single neurones of the rabbit superior cervical ganglion. Neuropharmacology 17: 1023-1028. 